\title{
O Direito Ambiental no Mercosul ${ }^{1}$
}

\author{
Virgínia Amaral da Cunha Scheibe
}

\section{INTRODUÇÃO}

A deterioração do meio ambiente é um processo que se vem desenvolvendo desde o princípio dos tempos, pela ação preda tória do homem sobre seu entorno. Todavia, nos dois últimos séculos e notadamente nesse Século XX que ora finda, assumiu proporçöes alarmantes, seja pelo acúmulo das agressões perpetradas ao longo do tempo, seja pelo incremento extraordinário das atividades produtoras lesivas, seja pelo só aumento da população do Planeta. Paralelamente a isso e certamente como decorrência desse fenômeno, vem se desenvolvendo uma progressiva consciência ecológica, uma preocupação crescente com a proteção à natureza, com a preservação do meio ambiente sadio e capaz de garantir o bem estar e a própria sobrevivência da geração presente e também das futuras geraçōes.

Considerando que a degradação ambiental atinge o planeta como um todo, produzindo efeitos que vão bem além das fronteiras de qualquer país e que mesmo a extensão transfronteiriça de certos bens ou sistemas a serem protegidos fazem com que seja muitas vezes inócua a proteção operante neste ou naquele tertitório, fica fácil compreender que não basta a ação isolada das nações, mas por tudo se recomenda que ajam em conjunto ou, ao menos, tenham o cuidado de manter patamares equilibrados de proteção em relação umas às outras.

Efetivamente, do ponto de vista exclusivamente do bem a ser protegido - o meio ambiente sadio e equilibrado, a ação de todos os países é indispensável: nenhum se pode eximir ou ficar para trás na luta preservacionista, cujo objetivo maior, já se disse, é assegurar a manutenção e a melhoria da vida no planeta, o que envolve ecossistemas integrados e grandes sistemas interligados. Como proteger a camada de ozônio, evitar o aquecimento das camadas polares e consequente elevação do nível dos mares e assegurar a preservação das coberturas florísticas, se aqui e ali se admitem as mais variadas agressões!

É, também quando os países se unem um ao outro com objetivos políticos ou mesmo meramente comerciais, que se proporcionam melhores meios e razōes para unificarem suas

\footnotetext{
1 Trabaho de conclusão ao Curso de Pós-Graduaçăo lato sensu da Faculdade de Ciências Juridicas e Sociais - Especialização em Direito Internacional - da Universidade Federal do Rio Grande do Sul, apresentado em 8 de novembro de 2000. Agradeço ao ilustre Colega, Professor Dr. Vladimir Passos de Freitas todo o incansável auxillo que, na condição de orientador, prestou-me na elaboração deste trabalho e o permanente incentivo à busca de maiores conhecimentos sobre o Direito Ambiental.
} 
políticas ambientais. A permanência do diálogo, das negociaçóes, facilita o trânsito do tema e o objetivo comum do incremento sócio-econômico praticamente dita a necessidade de interferências comuns no processo produtivo e mercadológico, como forma de garantir a competitividade entre países reunidos.

Destina-se o presente trabalho a abordar justamente as perspectivas de evolução das nomas ambientais em um contexto comunitário, mais precisamente o do Mercado Conum do Sul (MERCOSUL), sinalizando no rumo de propostas viáveis para o incremento de uma política ambiental que nele assegure a maior proteção, preservação e melhoria possíveis.

Para tanto, mister é que conheçamos a evolução desse processo de integração e de outros e tenhamos noção de como a questão ambiental vem sendo neles e no plano interno dos Estados-Parte sendo tratada e também conheçamos o que, apropósito do aperfeiçoamento do sistema, vem sendo sugerido pela doutrina.

Este trabalho tem, pois, o objetivo de prestar modesta colaboração àqueles que desejam entender como tem sido conduzido o processo integracionista e como nele tem evoluido o trato da questäo ambiental.

Antes de ingressarmos ao tema, propriamente dito, mister é que tenhamos presente que o processo de reunião de Estados em tomo de um objetivo comum, fomentado após a dolorosa experiência da Segunda Guerra Mundial, à base do conceito de solidariedade e da noção de que as Nações reunidas podem muito mais do que isoladas, criou condiçōes para o estabelecimento de inúmeros tratados internacionais e para o florescimento de organismos intemacionais de vocaçăo universal ou regional, como a ONU e a OEA, ou originários de blocos econômicos.

Já o esforço de integração no continente latino-americano vem também de longa data. Produziu alianças mais ou menos bem sucedidas ao longo do tempo, através das quais as nações latinas, hoje ditas em desenvolvimento, buscaram fazer frente aos grandes blocos políticos e econômicos, incrementando sua industrialização e seus recursos humanos, com vista à promoção do desenvolvimento econômico.

Compreensível que assim tenha sido, visto que o adiantamento do processo de industrialização dos países desenvolvidos transformou o continente sul-americano em mero mercado consumidor de produtos industrializados e fornecedor de matéria-prima aos países ricos,sem recursos financeiros nem autosuficiencia em tecnologia e recursos humanos especializados que permitissem alterar este jogo de poder:

Daí, pois, a noção corrente de que se fazia imperiosa a união solidária dos países sulamericanos, para fazer frente aos grandes blocos ou potências econômicas, com o fortalecimento do pan-americanismo.

A integração latino americana teve início com a criação da ALALC (Associação Latino-Americana de Livre Comércio). O CEPAL - órgão subsidiário do Conselho Econômico e Social da ONU, atualmente denominado "Comissão Econômica para a América Latina e Caribe", desenvolveu os primeiros estudos para a criação do mercado regional latino-americano, vindo a ALALCa ser constiturida pelo Tratado de Montevidéo de 1960, reunindo Argentina, Chile, Brasil, México, Paraguai, Perú, Uruguai, Colômbia, Equador, Venezuela e Bolívia. 
Em 1980, a ALALC foi substituida pela ALADI (Associação Latino-Americana de Integração), congregando Argentina, Bolívia, Brasil, Colômbia, Chile, Equador, México, Paraguai, Perú, Uruguai e Venezuela, prevendo a criação de um mercado comum latinoamericano, de estabelecimento gradual e progressivo.

O "PACTO ANDINO', por sua vez, é processo de integração sub-regional criado pelo Acordo de Cartagena, de 1969, visando o desenvolvimento da região para facilitar sua participaçăo na ALALC/ALADI que, por sua vez, como vimos, se pretenderia transformar em Mercado Comum. Atualmente, vige em estágio mais avançado que a ALADI, possuindo um Parlamento e uma Corte de Justiça, de escassa atuação. Foi aperfeiçoado em 1976 e é integrado por Perú, Equador, Colômbia, Bolívia e Venezuela.

Temos ainda o "Parlamento Latino-Americano" (PARLATINO) e o "Sistema Econômico Latino-Americano, instituido no Panamá, em 1975 e que engloba 26 países, voltandose à matéria econômica.

Por último, de registrar-se o "Mercado Comum do Sul", (MERCOSUL), instituido pelo Tratado de Assunção, em 1991, processo de integraçao atualmente constituindo zona de livre comércio, a reunir Brasil, Argentina, Paraguai e Uruguai. Constitui a mais ambiciosa tentativa de integração latino -americana, consoante analisa CELSO D. DE ALBUQUERQUE MELLO². Não se constitui, ainda, em Mercado Comum porque não dispóe de órgãos supranacionais, sendo sua estrutura apenas inter-governamental c estando, ainda, tecnicamente, em etapa de cooperaçãa econômica.

Assim, renovadas tentativas de integração econônica tem sido feitas no continente sul-americano, com maior ou menor sucesso e permanência.

Todavia, em nenhuma delas a questão ambiental assumiu o relevo que hoje assume no Mercosul, cujo Tratado constitutivo, em seus considerandos, indica a proteção ambiental como instrumento de integração. Tal fato reflete não só a preocupação que o tema desperta em cada um dos Estados-Membros, como o atual estágio de conscientização do Homem em relação à necessidade de preservação do habitat terreno como condição para garantir a própria sobrevivência no Planeta ao longo do tempo. Reflete também a noção, agora alcançada, de que a proteção ambiental e o desenvolvimento sustentável são condições que năo se podem deixar à margem de qualquer esforço integracionista e nele, aliás, deverá encontrar o caminho do necessário fortalecimento.

Este é o exemplo dado pela Comunidade Européia que, se náo pode ser indicada como paradigma absoluto na questão ambiental pela peculiaridade própria de estar voltada para o continente europeu, com características geofísicas, culturais e desenvolvimentistas distintas daquelas próprias da América do Sul, há de sê-lo como evidência de que não há processo de integração que possa perdurar no tempo e alcançar o almejado efeito de progresso e bem-estar social sem englobar medidas que garantam um meio ambiente saudável e equilibrado para hoje e para o futuro.

${ }^{2}$ MELLO, Celso D. de Albuquerque. Direito Internacional da Integração. Rjo de Janeiro: Livraria e Editora Renovar, 1996, p. 301 et seq. 
No busca de uma melhor compreensão do tema, analisaremos o trabalho que se tem feito, em tema de Direito Ambiental na União Européia, no próprio Mercosul até hoje e, internamente, nos países que o compõem.

\section{A DEFESA AMBIENTAL NA UNIĀOEUROPÉIA}

Oproblema ambiental no continente europeu vem de longa data, com diversos incidentes graves isolados, de repercusão em vários países e práticas agressivas comuns em todos eles, como o desmatamento desordenado e a poluição das águas. A proximidade dos países, entrou neste contexto como uma agravante, dado que as medidas tomadas por um país, nem sempre eram seguidas em outro. A circunstância faz-se especialmente significativa, se imaginarmos que a fonte poluidora situa-se em um país que elege não atacá-la ou não atacá-la eficazmente, e seus efeitos se propagam a outro ou outros, que sonente podem agir no sentido de minimizar o dano, sem poder para fazer cessar a causa.

De outra parte, a diversidade de condiçōes ambientais no continente, fato notório e decorrente do rítimo e da orientação desenvolvimentista de cada país, produziu diferentes danos neste e naquele território. Jáo relatório produzido no "Estado do ambiente na Comunidade, em 1986", conforme refere a publicação da Documentação Européia intitulada "A política de ambiente na Comunidade Européia", aponta ser acentuadamente grave a ameaça à vida selvagem na Espanhae em Portugal, do que nos outros páses do continente, bem como haver notório increnento de deposição ácida no solo e chuva ácida nas regiōes mais industrializadas, além de poluição das águas e amosférica de diversas origens.

Entretanto, embora o problemajá viesse de longa data, no primeiro encontro comunitário que se dispôs a adotar uma política formal de ambiente (Paris, 1972), não se cogitou de dar combate a agressões transfronteiriças . Assim, o primeiro programa de ação da Comunidade, adotado em 1973 e também no segundo, de 1977, não ingressou a tal enfoque nem fixou uma política de substância na área ambiental, limitando-se a dispor sobre a melhoria do meio ambiente em geral no âmbito do continente.

Foi na década de 80 , que se aclararam os principios dessa política substancial no âmbito da Comunidade. Foi então que se passou a pensar no princípio da prevenção, como basilar ao sistena protetivo, marco e fim do processo desenvolvimentista. Passou-se aentender que o desenvolvimento econômico e social deve ser realizado de maneira a năo prejudicar o meio ambiente. Lançava-se, então, o 3 o Programa de Ação da Comunidade (1983), onde se consagrou, além do mencionado princípio da prevençăo, a noção de que a proteção ambiental deve ser considerada na formulação de out as políticas nacionais e comunitárias.

Em 1987, no 40 programa de ação, confirmout-se a prioridade à prevenção e o meio ambiente passou a figurar como elemento essencial de qualquer política econônica e social.

É de dizer-se que a poluição aquática transfronteiriça, com a deposição de compostos de mercúrio no Rio Reno, nas proximidades de Basiléia/Súç̧a (novembro de 1986), causando notável mortandade de vidas aquáticas e marginais também na Alemanha, França e Países Baixose acarretando problema de abastecimento, e a poluição atmosférica destruindo as florestas alemäs, são fatos que a publicação lembra como aceleradores dessa tomada geral de consciência de que a poluição não conhece fronteiras e de que se impunha o seu combate conjunto. 
Na verdade, percebe-se que houve um processo lento de tomada de posição no sentido da necessidade de atuação conjunta na área ambiental e da primazia que tais objetivos deviam guardar no esforço comum pelo desenvolvimento sócio-econômico, como imperativo do maior ben-estar do homem. Tomou-se conrente, aos poucos, a noção de que produzir produtos "verdes" (através de procedimento ecologicamente corteto) é não só imediatamente mais proveitoso em face da preferência que desfrutam no mercado, como é medida que se impõe a benefício presente e futuro do homem em geral.

Veja-se que já en 1988 (3 de julho), surgiu a Diretiva da Comunidade sobre a avaliação do impacto ambiental nos projetos agrícolas, petrolíferos, energéticos, turísticos e de desenvolvimento regional. Paralelamente, muito se tem investido na descoberta de novas técnicas de produção inofensiva, saneamento, reciclagem, etc.

Evidentemente que todo esse esforço surge como tuma resposta das autoridades à pressão manifesta dos seguimentos que atuam na defesa da ecologia e da opiniáo pública em geral, traduzida em pesquisas de opinião que indicam a importância da temática, a demanda por uma urgente disciplina e a inclinação por uma política ambiental comun no seio da Comunidade.

Neste contexto, onde a instrumentação jurídica da ação política assume o papel de condicionante do sucesso dessa mesma ação, guarda especial relevo o ATO ÚNICO EUROPEU (1986/1987), que instituiu a proteção ao meio ambiente como una das políticas fundamentais da Comunidade, buscando assegurar o desenvolvimento sustentável.

Através dele, foi reconhecido, pela primeira vez, que é necessário "combinar os objetivos do livre comércio com um elevado nível de proteção ao Meio Ambiente, tal como o intento de fixar objetivos de natureza ambiental como um fim legítimoem sí."

Nele se afirmam os princípios da prevenção, da reparação na fonte e do poluidor-pagador e se introduz a proteção ao meio ambiente como uma componente de outras políticas da comunidade. Oprimeiro dos princípios mencionados traduz a máxima de que a melhor forma de proteger é prevenir a ocorrência do dano; o segundo, o de que a reparação do dano deve set buscada na fonte geradora, onde será muito mais eficaz, pela cessação ou controle da ação lesiva e não somente dos danos que na cadeia de tempo-espaço, se văo produzindo; por fim, oprincípio do poluidor-pagador busca a responsabilização do causador do dano por sua reparação, em lugar do repasse dos custos respectivo ao Estado e, por consequência, à toda a sociedade.

Por meio do A to Único também ficou assegurada a observância de normas protetivas mais rigorosas do que as comunitárias, desde que não incompativeis com o Tratado, o que assegura a evolução das legislações internas no sentido de maior proteção do que aquela que o consenso da Comunidade consegue fazer baixar. A idéia, passa, lógicamente, pela observancia do princípio da subsidiariedade, consoante alerta o ilustre professor da Universidade de Pávia, Itália, GIOVANNI CORDINI ${ }^{3}$, ao analisar aquele importante marco no progresso do direito ambiental europeu.

Embora os princípios consagrados no Ato Único sejam aqueles que centralizam a política ambiental da Comunidade, sua efetivação e o alcance dos objetivos visados passa pela

${ }^{3}$ CORDINI, Glovanni. O ambiente no Direito da Uniäo Européia. In: RTFR/4a. Região, Porto Alegre: Livraria do Advogado Editora, a. $8, \pi^{\circ} 28, p . .371$ et seq, 1997. 
necessidade de um considerável aporte financeiro, criando demanda por maior participação no orçamento comunitário, o que sempre está vinculado a esforços políticos e levando à busca de soluções que não só utilizem recursos públicos, mas propiciem meios para que a própria atividade econônica nos países nembros seja direcionada à obtenção de melhoria ambiental associada ao desenvolvimento sócio-econômico, notadamente nas regičes menos desenvolvidas, onde a degradação ambiental é mais sentida.

Na verdade, trata-se de envolver a iniciativa privada para que, associada aos esforços das autoridades comunitárias ou internas, façam com que as medidas protetivas resultem em incremento econômico, en progresso. É o caso, por exemplo, de incentivar o turismo, o aproveitamento de resíduos, o desenvolvimento de tecnologias limpas de mais baixo custo e a melhoria da produtividade agrícola

Os principais instrumentos fnanceiros utilizados pela Comunidade Européia com tal objetivo são o Fundo Social Europeu, a seç̧ăo Orientação do FEOGA e o Fundo Europeu do Desenvolvimento Regional, que financiam considerável número de projetos, notadamente nas regiōes menos desenvolvidas, que de 1989 a 1993, absorveram 1,2 mil milhóes de ecus. Neste contexto incumbe ainda mencionar os financiamentos do Banco Europeu de Investimento (BEI).

Ainda em 1989 foi estabelecido um programa especial - ENVIREG, destinado a solver o problema da poluição nas zonas litorâneas, mais especialmente no Mar Mediterrâneo e um programa complementar - MEDSPA, para abranger outras regióes litorâneas e países da bacia mediterrânea não integrantes da Comunidade. Através desses programas se atentará especialmente ao problema dos esgotos nas cidades, armazenamento de resíduos tóxicos perigosos, incentivo à reciclagem dos resíduos aproveitáveis.

O Banco Europeu de Investimento vem concedendo empréstimos de longo prazo e atualmente, com a inclusão de projetos relativos à proteçăo ambiental e exigência de relatório de impacto ambiental. Paralelamente, desenvolve esforços no sentido de que os projetos produtivos financiados envolvam o cuidado da poluição mínima.

Também neste caso se percele a canalização de esforços para forçar o empresariado a harmonizar a ação produtiva à política protecionista, e a preocupação em colaborar com projetos e estudos cujo objetivo é exclusivamente incrementar práticas protecionistas, como, a exemplo, a purificação do ar.

De notável importância, também, é o programa ACE (Açôes da comunidade relacionadas com o ambiente), que financia projetos de demonstração, incentivando o desenvolvimento de tecnologias apropriadas e novos métodos de controle ambiental.

Todo este esforço passa, por óbvio, pela ação popular de controle das atividades poluentes, com a denúncia de práticas lesivas, de campanhas de conscientização, de educação ambiental, enfim, pela mobilização do público no sentido de pressionar as autoridades de seu país a cumprir as normas internas e as diretivas da Comunidade Européia.

Neste aspecto, vale salientar que as diretivas da Comunidade devem ser ratificadas pela legislação nacional e esta deve ser adaptada para tal aplicação, processo durante o qual não é raro que os objetivos ou lineamentos primeiros da norma comunitária acabem sofrendo 
um certo desvirtuamento. É aí que a iniciativa popular pode executar o importante papel de denunciar o fato à Comissão Européia, propiciando o devido controle desta.

Claro está que sem a conscientização populat, sem a propagação dos malefícios que as ações danosas causam às gerações presentes e futuras e sem o incremento da participação do público em todos os projetos ambientais, năo se pode realizar um controle efetivo do meio ambiente e tudo isso passa pelo esforço de incentivar a participação popular e disseminar o conhecimento neste campo, seja desde as primeiras letras até o estudo superior, com o incentivo à formação de técnicos e cientistas da área.

Finalmente, no $5^{\circ}$ progtama de ação ambiental (1992), tratou-se da mudança nos hábitos de consumo, da partilha da responsabilidade, com interação de vários segmentos da sociedade e novamente se priorizou a observância do princípio da prevenção, notadamente com a exigência de avaliação do impacto ambiental de projetos nas áreas da agricultura, indústria petrolifera, energia, transportes, desenvolvimento regional e turismo.

É o que nos recorda a ilustre Profa. MARTHA LUCIA OLIVAR JIMENEZ ${ }^{4}$, no trabalho que ofereceu à Associação Brasileira de Estudos da Integração, em 1994. Ali, discorrendo sobre o $5^{\circ}$ Programa de Ação da Comunidade Européia, observa a Autora:

"Outros instrumentos jurídicos originados no quinto programa comunitário e ação pelo meio ambiente, estreitamente vinculados à efetividade do princípio da prevenção dos danos ambientais e da tealização do desenvolvimento sustentável, são: a possililidade para os produtores de colocar em seus produtos um logotipo, a "Eco-etiqueta", direito que será concedido por um organismo do Estado-Membro nacional em consideraçăo aos resultados ecológicos globais ao longo de sua atividade econômica e o diteito de colocar um logo, "Eco-audit" (denominação francesa) nos documentos comerciais (prospectos e folhetos, cabeçalhos de papéis e publicidade em geral). Este último consistiria em um instrumento de organização interna e um indicador do sucesso ecológico das atividades da empresa destinado aos acionistas, seguradores, financiadores, autoridades públicas e ao público em geral. Como vemos, o objetivo principal perseguido por estes instrumentos é o de melhorar o sistema de informação aos consumidores sobre o impacto ambiental dos produtos que eles adquirem."

Vê-se, pois, que a política ambiental no âmbito da Comunidade Européia desenvolveur. se de forma gradativa porém firme, no rumo do incremento das açóes oficiais e da participação popular crescente, envolvendo o interesse dos próprios setores produtivos en prestigiar a defesa ambiental, cono forma de gatantir-se perante um mercado cada vez mais exigente quanto a tal aspecto.

Por certo que a veiculação das normas comunitárias por via de diretiva que, consoante já observamos, não tem aplicação direta (o mais das vezes, diga-se, posto que já se defendeu com êxito o entendimento de que aquelas diretivas claras e completas são prontamente exeqüíveis), causa empeços à sua total observância no âmbito interno dos Países-Membros e constitui motivo para a delonga no processo de sua aplicabilidade.

4 JIMENEZ, Martha Lucia Olivar. O estabelecimento de uma polifica comum de proteçăo do meio ambiente - sua necessidade num mercado comum. In: BRASIL. Senado Federal. Estucos da Integração, Brasilia, v. 7, p. 39, 1994. 
Recente Comunicação da Comissão das Comunidades Européias ${ }^{5}$ dá conta de que já foram adotados mais de 200 atos de legislação ambiental da comunidade, a maior parte deles constituidos por diretivas já transpostas para a legislação intema dos Países-Membros, gerando hoje problemas relativos à sua aplicação prática e controle de sua aplicação. De outra parte, a revisão do 5o Programa de Ação da Comunidade em matéria de ambiente foi objeto de uma proposta da Comissão no sentido de tomar mais rápida sua implementação, medida indispensável ao respeito e observância de todo o acervo comunitário em matéria ambiental e à efetividade das políticas ambientais adotadas.

A experiência européia faz-se valiosa para a solução do problema ambiental nos países integrantes do Mercado Comum do Sul. Dela poderemos retirar os vetores para orientar os esforços comunitários para alcançar um nível hamônico de proteção ecológica no território.

De momento, o que temos, neste processo integracionista sul-americano ainda incipiente, são alguns acordos multilaterais, os esforços do organismo comunitário criado para tratar do tema e a legislação intema de cada país, a conferir maior ou menor nível de proteção.

Analisemos, agora, a proteção ambiental adotada até hoje pelo Mercosul, para, a seguir, passarmos à legislação ambiental dos quatro Países- Membros.

\section{ESTÁGIO ATUAL DA PROTEÇÃO AMBIENTAL NOMERCOSUL}

Primeiramente, de registrar-se que o Tratado de Assunção, firmado em 1991, que constitui o Mercado Comum do Sul a ser estabelecido gradativamente entre a República Argentina, a República Federativa do Brasil, a República Oriental do Uruguai e a República do Paraguai, não menciona a proteção ambiental dentre suas diretrizes. Todavia, como já referimos, seu preâmbulo a prevê como um instrumento da integração econôtmica almejada:

"Considerando que a ampliação das atuais dimensões de seus mercados nacionais, através da integração, constitui condição fundamental para alterar seus processos de desenvolvimento econômico com justiça social;

Entendendo que este objetivo deve ser alcançado por intermédio do mais eficaz aprimoramento dos recursos disponíveis, a preservação do neio ambiente, a melhoria das interconexões físicas, a coordenação das políticas macroeconômicas dos diferentes setores da economia, com base nos princípios de gradualidade, flexibilidade e equilíbrio."

Portanto, embora não enfocada sob a condição de obje tivo específico da aliança comercial, a proteção ao meio ambiente é adotada no Tratado constitutivo em causa, como forma de alcançar-se os objetivos integracionistas. Efetivamente, consoante lembra a ilustre professora LEILA DEVIA ${ }^{6}$, da Universidade de Buenos Aires, em diferentes subgrupos de trabalho, como na indústria, setor agropecuátio, etc., se tratou da questão ambiental e, por ocasião do Encontro de Las Leñas, em 1992, se resolveu criar a REMA - Reunião Especializada em Meio Ambiente, para detectar assimetrias políticas e legislativas que poderiam afetar a competitividade.

\footnotetext{
5 Revista de Direito Ambiental. Säo Paulo: RT, n. 14, p. 235-260, abr./jun. 1999.

s DEVIA, Leila. La politica ambiental en el marco del Tratado de Asuncion. In: BERTUCCl, Rosana et alii. Mercosur y Medio Ambiente. Buenos Aires: Ediciones Ciudad Argentina, p. 28, 1996.
} 
O trabalho desenvolvido pela Rema, posteriormente transformada no $6^{\circ}$ Sub-Grupo de Trabalho do MERCOSUL (ambiente), desenvolve-se no sentido de analisar a legislação ambiental dos Países Membros, as propostas de diretrizes e harmonizaçăo das políticas ambientais. Foi ali tratada amplamente a questão das barreiras e restriçōes não alfandegárias de caráter ambiental, pugnando-se por fazer coincidir sua gradual eliminação com a harmonização das normas ambientais nos diversos Estados. Foi conferida observância prioritária aos Tratados de proteção ao meio ambiente firmados pelos quatro Países - e dos quais mais adiante trataremos, e, por via da Resolução GMC n 10/94, foram aprovadas as diretrizes básicas em matéria ambiental. Igualmente, tratou-se de disciplinar um procedimento adequado ao cumprimento do proposto artigo 129, item 3 do Código Aduaneiro do Mercosul, dispondo sobre a eliminação de mercadorias perigosas à saúde e à vida das pessoas, animais, vegetais ou ao meio ambiente, no territónio aduaneiro.

Com a transformação da REMA em Sub-Grupo de Trabalho(1993/94), suas tarefas prioritárias, no desempenho de sua função de municiar o Grupo do Mercado Comum (GMC) - órgão decisório do MERCOSUL, com elementos técnicos para a tomada de decisões na área ambiental, são: a) o estudo das restrições não tarifárias, visando sua harmonização ou eliminação; b) o estabelecimento de regras que assegurem condições de adequada competitividade entre os Estados Parte, inclusive com análise do custo ambiental e do custo total do processo produtivo; c) elaboração de notmas sobre a adoção e implementação da Série ISO 14.000, gestão ambiental, com estudos sobre o impacto de sua aplicação como fator diferencial de competitividade para produtos originátios do MERCOSUL no mercado internacional; d) elaboração de documento que, a partir das diversas legislações nacionais do bloco, otimize os níveis de qualidade ambiental em todos os Estados-Membros, constituindo um projeto de instrumento jurídico de meio ambiente no MERCOSUL; e) criação de um sistema de informação ambiertal; f) criação do selo verde MERCOSUL.

De anotar-se que a 19.7.1998, tornou-se pública a minuta formulada ao documento único supramencionado, que denominou-se "Protocolo Adicional ao Tratado de Assunção sobre Meio Ambiente". Em seus considerandos enfatiza-se a necessidade de cooperação com vistas ao desenvolvimento sustentável, o compromisso de que as atividades econômicas de um Estado Membro não causem dano ao neio ambiente dos demais, a especial relevância do tema no processo de integração. Igualmente, nele se reafirmam: 1) a Declaração de Estocolmo sobre o Ambiente Humano, de 1972, base de desenvolvimento do direito ambiental em todo o Mundo e tida por constitucionalistas como um desdobramento da Declaração dos Direitos do Homem; e 2) a Declaração do Rio de Janeiro sobre Meio Ambiente e Desenvolvimento, de 1992.

Discorrendo também sobre o tema do meio ambiente no MERCOSUL, a ilustre professora paulista, ELDIS CAMARGONEVES DA CUNHA", lembra que no "Encontro de Canela", preparatório para a Rio'92, produziu-se a "Declaração de Canela", firmada pelos Presidentes dos Países Membros do MERCOSUL e do Chile, na qual destacou-se que "As

${ }^{7}$ CUNHA, Eldis Camargo Neves da. O Meio Ambiente no Tratado. In: BERTUCCl, Rosana et alij, Mercosur y Medio Ambiente. Buenos Aires: Ediciones Ciudad Argentina, p. 39, 1996. 
transações comerciais devem incluir os custos ambientais causados nas etapas produtivas, sem transferi-los às geraçóes futuras". Reafirmava-se, pois, no âmbito do Mercado Comum do Sul, o princípio do desenvolvimento sustentável, que foi definido pela "Comissão Mundial sobre o Meio Ambiente e Desenvolvimento", como "o desenvolvimento que atende às necessidades do presente sem comprometer a capacidade das futuras gerações atenderem às suas próprias necessidades".

A Declaração de Canelaé, sem dúvida, trabalho a merecer especial atenção do estudioso da proteção ambiental no Mercosul. Nela, nos Considerandos do Tratado de Assunção que já acima lembramos, e nos compromissos internacionais firmados pelos Estados Membros nessa área, vamos encontrar os objetivos e as bases para a formulação de uma política ambiental comum no âmbito do bloco e cujo projeto acha-se, como vimos, em fase de elaboração.

No plano internacional, o Mercosul, que adquiriu personalidade jurídica de Direito Internacional com o Protocolo Adicional ao Tratado de Assunção sobre a Estrutura Institucional do Mercosul (Protocolo de Ouro Preto, aprovado em 15.12.95), já firmou alguns tratados em materia ambiental.

Dentre estes, a Profa. MARISTELA BASSO menciona:

1) "Acordo sobre Cooperação em Matéria Ambiental", celebrado pelos quatro EstadosMembro em 1992 e internalizado em 1997, e que, entre outras medidas, trata de priorizar o tratamento das questóes ambientais em áreas fronteiriças; $\mathrm{e}$

2)"Acordo Bilateral entre a República Federativa do Brasil e a República Argentina sobre Cooperação em Matéria Ambiental", frmado em Buenos Aires, em abril de 1996, envolvendo ecossistemas de regiōes limítrofes, frente ao incremento da movimentação populacional, de mercadorias e de serviços, em face de projetos que envolvem também a integração física entre os dois países.

Visto, pois, em linhas gerais, o panorama que se desenha a nível conunitário em relação ao meio ambiente, ingressemos à análise do ordenamento interno de cada Estado-Membro.

\section{A DEFESA AMBIENTALNAS LEGISLAÇÕES DOS ESTADOS.PARTEDO MERCOSUL}

\subsection{A legislação argentina}

A Constituição da Nação Argentina, promulgada em 1853, sofreu reformas em 1860 , 1866,1898,1957 e 1994, esta última, em razão da Lei 24.309, de 29 de dezembro de 1993, que declarou necessária a reforma e autorizou a Convenção Constituinte a introduzir regra de preservação ambiental e da ação de amparo.

Em tais tennos, o Capítulo Segundo da Carta, destinado a dispor sobre novos direitos e garantias, passou a contar com as seguintes disposições:

"Artículo 41 - Todos los habitantes gozam del derecho a um ambiente sano, equilibrado, apto para el desarrollo humano y para que las actividades productivas satisfagam las necesidades

${ }^{8}$ BASSO, Maristela. Livre Circulação de Mercadorias e Proteção Ambiental no Mercosul. In: BASSO, Maristela et alil. Mercosul: seus efeitos juridicos, econômicos e politicos nos Estados-Membros. 2. ed. Porto Alegre: Editora Livraria do Advogado, p. 359 et seq, 1997. 
presentes sin comprometer las de las generaciones futuras; y tienem el deber de preservarto. El daño ambiental generará prioritariamente la obligación de recomponer, según lo estabelezca la ley.

Las autoridades proveerán a la protección de este derecho, a la utilización racional de los recursos naturales, a la preservación del património natural y cultural y de la diversidad biológica, y a la información y educación ambientales.

Corresponde a la Nacion dictar las normas que contengam los presupuestos mínimos de protección, y a las províncias, las necesárias para complementarlas, sin que aquéllas alteren las jurisdicciones locales.

Se prohibe el ingreso al território nacional de resíduos actual o potencialmente peligrosos, y de los radiactivos."

"Art.43 - Toda persona puede interponer acción expedita y rápida de amparo, simpre que no exista otro medio judicial más idóneo, contra todo acto u omisión de autoridades públicas o de particulares, que en forma actual o inminente lesione, restrinja, altere o amenace, com arbitrariedad o ilegalidad manifiesta, derechos y garantias reconocidos por esta Constitución, um tratado o una ley. En el caso, el juez podrá declarar la inconstitucionalidad de la norma em que se funde el acto u omissión lesiva.

Podrán interponer esta accion contra cualquier forma de discriminación y en lo rełativo a los derechos que protegen al ambiente, a la competencia, al usuário y al consumidor, como a los derechos de incidência colectiva em general, el afectado, el defensor del pueblo y las asociaciones que propendan a esos fines, registradas conforme a la ley, la que determinará los requisitos y formas de su organización.

... (omissis)"

Vê-se que a Carta consagra alguns dos princípios atuais em tema de defesa ambiental e dos quais acima já cuidamos. Primeiramente, consagra como direito fundamental o de um ambiente saudável e estabelece a preservação como um dever de todos, traduzindo a idéia de repartir responsabilidades, de envolver a todos na busca de soluçóes, nos cuidados e na fiscalização permanente sobre as ações efetiva ou potencialmente lesivas. Ademais, estabelece o comprometimento dos setores produtivos não só con as gerações presentes, mas também com as futuras, traduzindo a dimensão que hoje se atribui ao dever de preseryação, tendo em vista a continuidade da vida sobre o planeta (idéia do desenvolvimento sustentado). Deixa claro ainda o dispositivo, que a recomposição do dano é medida prioritária, não sendo o caso de admitir-se que a indenizaçăo satisfaça nos casos em que recompor o meio ambiente atingido seja ainda possivel e, finalmente, consagra o princípio do poluidor-pagador, atribuindo-the a condição de obrigado à tarefa de recomposição ou da composição.

Estabelece ainda o Texto como dever da Administração promover a proteção ao direito a um sadio e equilibrado ambiente, com a utilização racional dos recursos naturais, preservação do patrimônio respectivo e desenvolvimento da informação e da educação ambiental. Compromete, por essa via, o Estado-Administrador no esforço preservacionista e no incentivo à participação popular pela via da indispensável informação e da educação ambientalista, que já se viu consistirem em indispensável suporte a qualquer ação nessa área. 
Por último, o legislador constituinte assegurou o uso da ação de amparo também para proteger direitos que protegem o meio ambiente, o que constitui notável avanço no campo da efetividade da jurisdição nessa área, onde a ação rápida dos poderes institucionaisé, o mais das vezes, condição primeira de sucesso da intervenção estatal. Se a ação danosa (ou de potencial danoso) está en curso ou em vias de realização, muito pouco aproveitaria o decreto de sua ilegalidade após um procedimento ordinário, no qual restaria apenas estabelecer a responsabilidade civil correspondente. A possibilidade de uma pronta resposta jurisdicional atende, como se vê, ao princípio da precaução ou prevenção, coibindo a continuidade ou o início da ação deletérea. Sua consagração a nível constitucional constitui avanço significativo na legislaçăo argentina, inclusive com a outorga de legitimidade ativa a substitutos processuais extraordinários, como o Defensor Público e Associaçóes de objetivos protecionistas.

É de dizer-se, ainda, que a Carta estabelece o sistema de compartilhamento das competências legislativas, de maneira a reservar à União o estabelecimento das garantias mínimas de proteção, cabendo às províncias a tarefa de baixar normas complementares, sem interferir nas normas locais, de incidência estrita sobre o territótio de cada unidade municipal.

Discorrendo sobre tal aspecto, LEILA DEVIA' observa que:

"Además, las províncias puedem dictar legislación complementaria a la que dicte la Nación.

Por lo tanto existirá legislación de protección mínima, común a todo el territótio, y legislación provincial complementar, que puede contener mayores exigências que la normativa nacional aplicable a su ámbito. Pero toda la legislación, federal y provincial, será aplicada em las províncias por las autoridades administrativas y judiciales locales. Nos encontramos com legislación federal (pressupuestos mínimos), que en las províncias será aplicada por autoridades provinciales. Por ejemplo, la Nación podrá determinar los niveles de contaminación permitidos para el recurso agua, pero si la provincia de Buenos Aires quiere imponer exigencias mayores para los cursos de agua existentes em su territorio, podrá hacerlo dictando las normas complementárias."

Tal aspecto é de suma importância para a compreensăo do sistema jurídico argentino em tema protecionisista, valendo anotar que também por noma constitucional, mantida no Texto atual, as provincias gozan de competência legislativa residual, o que lhes garante baixarem nomas ambientais nas respectivas constituições.

Assim, antes mesmo da reforma de 1994, a maioria das constituiçóes provinciais argentinas consagravamo direito a um meio ambiente sadio, dando azo à formulação de legislaçöes provinciais protetivas.

Outro dado importante em tal período, foi terem a Nação e as Províncias firmado, em juho de 1993, "Pacto Federal Ambiental", buscando promover políticas de desenvolvimento ambiental adequadas em todo o território nacional, sob a cordenação do Conselho Federal do Meio Ambiente (COFEMA), órgão de coordenação da política ambiental na Argentina, como forma de uniformizar o trato da materia, pulverizado em muitas leis esparsas.

${ }^{9}$ DEVIA, Leila. Legislacion Ambiental de la República Argentina. In: BERTUCCl, Rosana et alï. Mercosur y Medio Ambiente. Buenos Alres: Ediciones Ciudad Argentina, p. 83-85, 1996. 
De dizer-se, ainda, que as leis orgânicas dos Municípios, delimitando as competências que thes são delegadas pelas respectivas Províncias, definem dentre suas responsabilidades, várias medidas de caráter ambiental, como coleta e depósito de lixo, água potável, deposição de resíduos, ruído, contaminação do ar, etc. A exemplo, anota LELLA DEVIA ${ }^{10}, 0$ "Código de Prevenção da Contaminação Ambiental", baixada pela Ordenanza 39.025/83, da Cidade de Buenos Aires.

A par da legislação esparsa, que é numerosa, o Código Civil, o Código Penal, o Código Aeronáutico e o Código de Mineração contém regras ambientais e em todos os níveis, instituições específicas para a promoção de um meio ambiente saudável atuam.

Todo esse esforço se direciona à proteção dos recursos naturais, notadamente da água, do ar, do solo, da fauna, das florestas, além de dispôr sobre a higiene urbana e os resíduos perigosos, valendo teferir que desde 1992, através da Lei24.197 (embora vetada) já se dispunha sobre a necessidade de prévio estudo do impacto ambiental na aprovação de projetos industriais, havendo também legislação que o preveja para as atividades de mineração, de construção de grandes represas, de expansão dos parques geradores de energia e de projetos de forte impacto ambiental que envolvam investimentos públicos.

No campo internacional, a Argentina é signatária de diversos acordos e tratados, que, por força do que dispōe o art.75, Inciso 22 da Constituição, tem hierarquia superior à das leis, 0 que confere a tais instrumentos jurídicos, a estabilidade indispensável. Dentre os vários acordos, convênios e protocolos firmados pela Nação Argentina, destacam-se:

1. Convênio para proscrição de experiências com armas nucleares (Lei 23.340/87)

2. Convênio sobre prevenção da contaminação marítima por dejetos e outros materiais (Lei21.947/79)

3.Convênio de Viena sobre proteção à camada de ozônio (Lei 23.724/89).

4.Convênio sobre a mudança climática (Lei 24.295/94)

5.Convênio sobre a biodiversidade (Lei24.375/94)

Como se pode ver desta breve resenha, a Argentina dispöe de excelente arsenal legislativo para enfrentamento da questăo ambiental e para tornar-se importante aliada dos países que lutam pela melhoria do meio ambiente. Seu Poder Judiciário, por sua vez, vem firmando tradiçāo de excelentes decisões na matéria, de que são exemplos os acórdãos produzidos nos casos 91.869, Maria del Carmen Pinini de Pérez x Copetro S/A, Tribunal de La Plata, Sala II, em 27.4.1993 ("La Ley" - t.1994-A), dispondo sobre a obrigação de indenizar por danos atmosféricos, e 1866, Hugo N. Almada x Copetro S/A y otro, Margarita Irazu x Copetro S/A y otro, Juan j. Klaus $x$ Copetro S/A y otro, Tribunal de La Plata, em 19.5.1998, dispondo sobre a composição de dano ambiental ("La Ley Buenos Aires" - 1998).

\subsection{A legislação paraguaia}

A Constituiçấo Nacional do Paraguai, promulgada em 20 de junho de 1992, consagra a proteção ambiental como um direito fundamental do homem. Em seu Título Il ("De los

${ }^{10}$ Devia, op.cit. p. 89. 
Derechos, de Los Deberes y de Las Garantias), Capítulo I ("De la vida y del ambiente"), Seccion II ("Del ambiente"), faz constar:

"Artículo 7. Del derecho a um anbiente saludable

Toda persona tiene derecho a habitar em un ambiente saludable y ecológicamente equilibrado.

Constituyen objetivos prioritarios de interés social la preservación, la conservación, la recomposición y el mejoramiento del ambiente, as como su conciliación con el desartollo humano integral. Estos propósitos orientarán la legislación y la política gubernamental pertinente."

"Artículo 8. De la protección ambiental

Las actividades suscep tibles de producir alteración ambiental será reguladas por la ley. Asimismo, esta prodrá restringir o prohibir aquéllas que califique peligrosas.

Se prohibe la fabricación, el montaje, la importación, la conercialización, la posesión o el uso de armas nucleares, químicas y biológicas, asi como la introducion al país de tesíduos tóxicos. La ley podrá extender esta prohibición a otros elementos peligrosos; asimismo regulará el tráfico de recursos genéticos y de su tecnologia, precautelando los intereses nacionales.

El delito ecológico será definido y sancionado por la ley. Todo daño al ambiente importará la obligación de recomponer e indemnizar.

Toda persona o grupo amenazado de ser privado de tal derecho puede exigir de las autoridades la protección o la intervención para impedir el daño."

Pelo que se vê o direito a un saudável ambiente está erigido à condição de princípio constitucional assecuratório de direito fundamental do homem. A Carta também consagra o princípio da precaução, o princípio do poluidor-pagador, adota o desenvolvimento sustentável, estabelece a obrigatoriedade geral de todos, incluindo o Estado e as instituições, na busca da preservação e melhoramento do meio ambiente.

O terceiro parágrafo do dispositivo consagra a legitimidade de qualquer pessoa, independentemente de sua nacionalidade e da condição de habitante do país, a reclamar contra qualquer ato lesivo ou potencialmente lesivo ao direito constitucionalmente assegurado, o que constitui notável avanço no trato da matéria.

A Carta, como se vê da transcrição supra, enfatiza a necessidade de adequação da legislação inferior e determina a penalização do delito ambiental, assim como cria a obrigação de recompor e de indenizat.

Sob tais luzes, várias leis foram baixadas e se criaram ou fortaleceram instituições aptas, dentre as quais se destaca a "Comissão Nacional de Defesa dos Recursos Naturais", criada por lei de 1990, com o objetivo de avaliar e orientar a política ambiental.

Dispóe ainda a Constituição Nacional, que a reforma agrária e o desenvolvimento rural se farão de acordo, entre outros ítens, com a defesa e preservação do ambiente (Art.115, ítem 7) e que os municípios tem competência para deliberar, entre outras, em matéria de ambiente (Art. 168).

Destacam-se, como suporte às açóes judiciais cabíveis para a efetivação da proteção desejável, as disposiçōes dos art. 38,39 e 40 do Texto, nas seguintes letras: 
"Artículo 38. Del derecho a la defensa de los intereses difusos.

Toda persona tiene derecho, individual o colectivamente, a reclamar a las autoridades públicas medidas para la defensa del ambiente, de la integridad del hábitat, de la salubridad pública, del acervo cultural nacional, de los intereses del consumidor y de otros que, por su naturaleza jurídica, pertenezcan a la comunidad y hagan relacion com la calidad de vida y con. el patrimônio colectivo."

"Artículo 39. Del derecho a la indemnización justa y adecuada.

Toda persona tiene derecho a ser indemnizada justa y adecuadamente por los daños o perjuícios do que fuere objeto por parte del Estado. La ley relamentará este derecho."

"Artículo 40. Del derecho a peticionar a las autoridades.

'Toda persona, individual o colectivamente y sin requisitos especiales, tiene derecho a peticionar a las autoridades, por escrito, quienes deberán responder dentro del plazo y según las modalidades que la ley determine. Se reputará denegada toda peticion que no obtuviese respuesta en dicho plazo."

Por último, incumbe ainda referir que a Constituição de 1992 , por seus artigos 161 e 163 , estabeleceu os Govemos Departamentais, fixando-lhes a competência, inclusive para preparar o plano de desenvolvimento departamental cooordenando-o ao Plano Nacionale, sobretudo reservou-thes, além daquelas ali definidas, as competências que a lei lhes outorgarem.

Neste aspecto, vale mencionar que a Lei $426 / 94$, que estabelece a carta orgânica do Governo Departamental, indica entre seus objetivos e faculdades, as de adotar medidas para a preservação das comunidades indígenas ali residentes e do meio ambiente e dos recursos naturais do Departamento.

Por aí já se vê que a legislaçấo ambiental no Paraguai, a exemplo do que ocorre na Argentina, se pode desenvolver no plano nacional, departamental e municipal, consoante, por óbvio, a abrangência das medidas ditadas e a necessidade de integração da ação estatal

ROBERTO RUIZ DIAZ LABRANO 11 lembra que as açōes defensivas poden ser propostas tanto por agentes públicos como por particulares, sendo que no respeitante a estes últimos, consoante o previsto em antigos Estatutos, como o Código Civil (Lei 1183/85), com diversos dispositivos que legitimam o particular a defender interesses próprios ou interesses comunitários que o aferem, notadanente, no campo do uso nocivo da propriedade e o Código Rural (Lei 1248/31), como estabelecimento de limitações que, enbora não suficientes, colaboram na preservação ambiental, no que diz com cuidados mínimos na exploração agropecuária, no que diz com o regime de águas e com o regime florestal (especialmente acerca de reservas florestais, conservação de terrenos montanhosos, exploração de madeira e reflorestamento).

Ademais, a Constituição confere ao Ministério Público relevante papel na defesa do meio ambiente e outros interesses diffusos, ao dispôr:

"Art. 266 - De la composición y de las funciones

El Ministério Público representa a la sociedad ante los órganos jurisdiccionales del Estado, gozando de autonomia funcional y administrativa em el cumplimiento de sus deberes "LABRANO, Roberto Ruiz Diaz. La defensa y preservacion del medio ambiente en el ordenamiento juridico del Paraguay. In: BERTUCCl, Rosana et a!li. Mercosur y Medio Ambiente. Buenos Aires: Ediciones Ciudad Argentina, p. 109 et seq, 1996. 
y atribuciones. Lo ejercen el Fiscal General del Estado y los agentes fiscales, en la forma deteminada por la ley."

"Art. 268. De los deberes y de las atribuciones

Son deberes y atribuciones del Ministerio Público:

1. Velar por es respeto de los derechos y de las garantias constitucionales;

2. promover acción penal pública para defender el patrimonio público y social, el medio ambiente y otros intereses difusos, así como los derechos de los pueblos indígenas;

3. ejercer acción penal em los casos em que, para iniciarla o proseguirla, no fuese necesaria instancia de parte, sin perjuício de que el juez o tribunal proceda de ofício, cuando lo determine la ley;

4. recabar información de las funcionários públicos para el mejor cumplimiento de sus funciones $y$

5. los demás deberes y ataribuciones que fije la ley."

Assim, legitimado à propositura da ação penal pública em matéria de meio ambiente, ao Ministério Público se impõe o dever funcional de zelar pela mais ampla e efetiva punição dos delitos ambientais. De ressaltar-se, entretanto, não estar ainda o "parquet" legitimado à propositura de ação civil pública.

Também importante papel está reservado ao Defensor Público, de que trata o art. 276 da Carta, como agente impulsionador de denúncia e agilizador de procedimentos, na qualidade de delegado parlamentar (sem competência judicial ou executiva), encarregado de evitar a desídia ou a falta de interesses das autoridades, na defesa dos direitos humanos e na proteção de interesses comunitários.

Sob o enfoque da legislação federal, merece destaque especial a Lei 294/93, que dispóe sobre a avaliação do impacto ambiental a toda a obra que possa, como consequência positiva ou negativa, direta ou indireta, afetar a vida em geral, a biodiversidade, a qualidade ou quantidade significativa dos recursos naturais ou ambientais e seu aproveitamento, o bemestar, a saúde, a seguridade pessoal, os hábitos e costumes, o patrimônio cultural ou os meios de vida legítimos. Igualmente, aquele diploma exige a avaliação como condição para diversas intervençôes públicas necessárias em projetos, como, a exemplo, para a obtenção de autorizaçăo.

Ainda relevam as leis 716 e 536, reguladoras, a primeira, dos delitos contra o meio ambiente e a segunda, sobre o incentivo ao florestamento e ao reflorestamento.

Retornando à já anotada competência dos municípios para legislar em matéria ambiental, conferida pelo art. 168 da Carta Maior, tem-se que dá margem a uma gama considerável de "ordenanzas" específicas, baixadas à luz das leis orgânicas das municipalidades, com destaque à extensa produção destes textos no Município de Assunção, a propósito dos mais variados aspectos ambientais em seus territótio, desde a higiene urbana até a conservação de parques e áreas preservadas.

No plano jurídico internacional, de anotar-se que o Paraguai é signatário de alguns Acordos e Tratados, dentre os quais DIAZ LABRANO ${ }^{\text {i2 }}$ destaca:

${ }^{12}$ Labrano, op.cit. p.189-192. 
1. Acordo para a proteção da flora, da fauna e das belezas cênicas naturais dos países da América, ratificado pelo Paraguai em 1981.

2. Convenção para a proteção do patrimônio mundial cultural e nacional, Paris, 1972.

3. Acordo sobre a proibição de desenvolvimento, produção e armazenamento de armas bacteriológicas e tóxicas e sobre sua destruição, ratificado pelo Paraguai em 1976.

4. Acordo sobre o Direito do Mar, Nações Unidas, tatificado pelo Paraguai em 1976.

5. Acordo sobre a constituiçāo do Comité Regional de Sanidade Vegetal(COSAVE), ratificado pelo Paraguai, em 1990. 1992.

6. Acordo de Viena para a proteção da camada de ozônio, ratificado pelo Paraguai, em

7. Tratado bilateral para a construção da Hidrelétrica de Itaipú .

Já do "Guia de Derecho Ambiental del Paraguay, publicação da ONG "Instituto de Derecho ambiental" (IDEA), dá destaque ainda ao Tratado de Yacyrerá, firmado com a Argentina e ao convênio também firmado com aquela República, sobre o aproveitamento múltiplo do Rio Paraná (Proyecto CORPUS, 1974).

As instituiçóes nacionais mais envolvidas com o tema ambiental são: a Universidade Nacional de Assunção, à qual se acha vinculada a Comissão Nacional de Energia Atômica; o Instituto do Bem -Estar Rural e o Serviço Florestal Nacional, vinculados ao Ministério da Agricultura; também vinculados a este Ministério, a Direção de Otdenamento Ambiental que, conforme a Lei 294/93, encartega-se das avaliações de impacto ambiental e a Direção dos Parques Nacionais e Vida Silvestre; o Serviço Nacional de Saneamento Ambiental (SENASA) e as Juntas de Saneamento ambiental, vinculados ao Ministério da Saúde Pública e Bem-Estar Social.

Desta resumida compilação, percebe-se que o ordenamento jurídico do Paraguai, no tema ambiental, já a partir do texto constitucional, que erige o meio ambiente saudável como direito fundamental do homem e legitima qualquer pessoa a defendê-lo, proporciona bons instrumentos para a efetivação da proteção ambiental.

Todavia, consoante anota ainda DIAZ LABRANO ${ }^{13}$, embora a instrumentalidade interna seja tazoável, a efetividade da defesa ambiental ainda deixa bastante a desejar na vizinha república, proporcionando ações predatórias que atingem de forma significativa a vida vegetal e animal, com enorme redução das florestas do País, indicandó-se como urgente o trabalho em busca de maior conscientização do povo e das autoridades, e meios para fazer cumprit as leis de proteção.

De particular relevo, anotar-se que a Constituição Nacional do Paraguai não prevê para as leis que aprovam tratados ou acordos internacionais, a mesma hierarquia de normas constitucionais. Todavia, de acordo com o art.137, a Carta lhe confere hierarquia superior à das leis:

"Art.137 - De la supremacia de la Constitución:

"La Ley suprema de la República es la Constitución. Esta, los tratados, convênios ou acuerdos intemacionales aprobados y ratificados, las leyes dictadas por el Congreso y otras

is Labrano, op.cit. 
disposiciones jurídicas de inferior jerarquia, sancionadas em consecuencia, integran el derecho positivo nacional em el orden de prelación enunciados."

\subsection{A legislação uruguaia}

Relatam os estudiosos que a República do Uruguai quase naao cuidou específicamente de problemas ecológicos em décadas anteriotes, dado que pelos mesmos não fora até então grandemente atingida, devido a năo ter um grande parque industrial, nem superpopulação, estando também protegido por um regime especial de ventos na região, com a tenovação constante do ar.

Assim é que as Constituições de 1830, 1917, 1934, 1942, 1952, 1966 e suas emendas de 1989 e 1994, não contém protetiva específica nessa área, trabalhando os juristas com o sistema de direitos e garantias implícitas, a cavaleiro das disposições dos art.s 7,72 e 332 da Carta, na redação que ainda hoje se mantém, e que metecem transcrição:

"Artículo 7- Los habitantes de la República tienem derecho a ser protegidos em el goce de su vida, honor, libertad, seguridade, trabajo y propriedad.

Nadie puede ser privado de esteos derechos sino conforme a las leyes que se establecen por razones de interés general."

"Artículo 72 - La enumeración de derechos, deberes y garantias hecha por la Constitución no excluye los otros que son inherentes a la personalidade humana o se derivan de la forma republicana de gobiemo."

"Artículo 332 - Los preceptos de la presente Constitución que reconocen derechos a los individuos, así como los que atribuyen facultades e imponen deberes a las autoridades públicas, no dejarán de aplicarse por falta de la reglamentación respectiva, sino que ésta será suplida, recurriendo a los fundamentos de leyes análogas, a los princípios generales de derecho y a las doctrinas generalmente admitidas."

Como categoria dos direitos humanos de terceira geração, os chamados "direitos da solidariedade", o direito a um meio ambiente sadio e equilibrado, constituindo o que se pode entender como direito inerente à personalidade humana ou direito à vida, recebe o reconhecimento e agarantia constitucional implícita.

Por outro lado, através do reconhecimento da função social da propriedade (art. 32), da instituição da defesa do patrimônio artístico e cultural como dever do Estado (art.34), da obrigatoriedade de legislação protetiva à saúde e à higiene públicas (art. 44), da instituição da responsabilidade civil do Estado por danos a terceiros (art.24), a Carta conferia um razoável suporte à defesa ambiental, em que pese demandasse interpretação.

Já a partir da Emenda de 8 de dezembro de 1996, significativo avanço verificou-se ná Carta, como reconhecimento da proteção ambiental como sendo do interesse de todos, por norma inserida na Seção que trata dos Direitos, Deveres e Garantias.

Efetivamente, por via da redação que tomou 0 artigo 48 , reconheceu-se a existencia do interesse geral na proteção ao meio ambiente, o que vale dizer, seu reconhecimento como direito difuso, e se consagrou a obrigaçāo de abstenção geral de ações lesivas, com remessa direta ao legislador ordinário, para as normas complementares: 
"Artículo 47. La protección del medio ambiente es de interés general. Las personas deberán abstnerse de cualquier acto que cause depredación, destrucción o contaminación graves al medio ambiente. La Ley reglamentará esta disposición y podrá prever sanciones para los transgesores"

O dispositivo abre espaço para a sanção administrativa ou penal das ações lesivas ao meio ambiente, sem referir-se, no entanto, à observância do princípio da precaução, vale dizer, dispondo somente sobre o dano já concretizado. Todavia, há que entender-se, por interpretação sistemática, que, garantido o direito ao meio ambiente saudável e reconhecido o interesse geral em protegê-lo (direito difuso), por via implícita se admite que tal proteção também se dê de forma preventiva, fazendo cessar a ação ou o projeto de ação potencialmente lesiva. Absurdo seria, face ao que na atualidade do Direito Ambiental se pensa, e portanto ao que se pode denominar de "doutrinas geralmente admitidas", na feliz expressão do já transcrito art. 332 da Carta Uruguaia, pensar-se que a desejada proteção ambiental somente possa dar-se na via da composição do dano ou da recomposição, quando ainda possível.

Assim, tem-se que a novel disposição abre ensejo a que se incremente de forma extraordinária o sucesso do esforço na busca de uma maior efetividade da proteção ambiental em todo o território uruguaio, nas mais variadas áreas, além daquelas onde hoje mais se faz atuante, ou seja, na higiene urbana, no controle da poluição do ar e da contaminação das águas.

Aliás, de anotar-se que OSVALDO MANTERO DE SAN VICENTE ${ }^{14}$, discortendo sobre os problemas ambientais no Uruguai, refere ser equivocada ou ultrapassada a noção corrente de que o país não tem grandes problemas ambientais. Diz o eminente professor e pesquisador :

"El escaso desarrollo industrial del país, así como su baja densidad de población podrian hacer pensar que Uruguay no padece graves problemas ambientales. Sin embargo, no es así. Como suele suceder em los países subdesarrollados, las dificultades económicas y muchas veces la idea no manifestada, pero admitida tácitamente de que es preferible lograr la industrialización del país aún a costa de la pétdida del equilibrio ecológico, constituyen el origem de sus problemas ambientales."

Dentre os problemas que detecta aquela autoridade em direio ambiental, acham-se a erosão do solo, a destruição da flora e da fauna naturais, a poluição das águas fluviais em decorrência dos despejos industriais aumentados pelo desmembramento das unidades fabris pelo interior do país, e as grandes obras de transformação das estruturas, afetando vários ecossitemas.

Justifica-se, assim, a adoção, notadamente na década de 90 , de vários diplomas legais

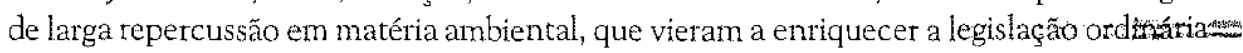
federal.

Nela, temos a destacar as normas do Código Penal relativas aos delitos contra a saúde pública, como ao envenenamento ou adulteração de águas ou produtos destinados à alimentação

14 SAN VICENTE, Osvaldo Mantero de. Derecho Ambiental. Colaboración de Daniela Cabral. Montevidéo: Ed. Fundacion de Cultura Universitária, p. 21-23, 1995. 
pública; o Código de Águas, a Lei Florestal e de Recursos Florestais, e a Lei de Impacto Ambiental, que declara de interesse geral e nacional (difuso), a proteção e recomposição do meio ambiente e a prevenção do impacto ambiental negativo ou nocivo, valendo referir que tais matérias, assim como a preservação do mar territorial são consideradas de competência nacional.

No que pertine especialmente à lei 16.466 (Lei de Impacto Ambiental), tem-se que criou o Ministério da Habitação, Ordenamento Territorial e Meio Ambiente, atribuindo-lhe a competência para autorizar o início de atividades, construçóes ou obras que causem impacto ambiental, bem como suspender ou fazer cessat atos que afetem o ecossistema e impor puniçóes administrativas, como a interdiçăo. O procedimento do estudo de impacto ambiental, estabelecido pelo decreto 436/994, estabelece que qualquer interessado pode opor objeção ao projeto e nele deve realizar-se audiência pública.

Já no plano da legislação departamental, baixada en consonância com o poder que às Juntas Departamentais é conferido pelo art. 273 da Constituição, tem-se a registrar que todos os governos departamentais tem baixado normas de proteção ambiental, sendo que em Montevidéo se criou, inclusive, uma administração de política ambiental.

Do ponto de vista institucional, é de dizer-se ainda que não sóo Ministério de Habitaçăo, Ordenamento Territorial e Meio Ambiente exerce funçōes relativas à proteção ambiental, se não que vários outros Ministério dispóem de departamentos onde a matéria é objeto de análise.

Já referimos que o Uruguai é protegido por uma especial regime de ventos que propotciona a permanente renovação do ar, de maneira tal que a poluição, neste campo, fazse restrita a pontos isolados, notadamente causada por eflúvios industriais em zonas densamente povoadas de Montevidéo. Por outro lado, outro motivo de preocupação é a higiene urbana, com o depósito do lixo e a contaminação das águas.

Oproblema da poluição do ar ocasionada pela atividade industrial está sendo amenizado pela aplicação da Lei do Impacto Ambiental e a conservação e aproveitamento das águas vem sendo disciplinado, desde a década de 70, pelo Código de Águas (Lei 13.833, de 1969).

Merecem especial destaque os tratados com países limírrofes, a propósito das águas fronteiriças. Com a Argentina, foi firmado o "Tratado del Río de la Plata y Su Frente Marítimo (ratificado em 1974) e o "Estatuto del Rio" (relativo ao Rio Uruguai, ratificado em 1976), Ambos dedicam capítulo à qualidade da água e à prevenção de sua contaminação, estabelecendo ainda obrigações de mútua colaboração.

Com o Brasil, o Uruguai firmou o "Tratado sobre Cooperación para el Aprovechaniento de los Recursos Naturales de la Cuenca de la Laguna Merín" (sobre o aproveitamento das águas da Lagoa Mirim/RS, ratificado em 1977, pela Lei 14.748), prevendo a uniformização de regras sobre aptoveitamento, consetvação e exploração de recursos vivos, entre outras.

Quanto à preservação do solo, especialmente no que pertine aos depósitos e eliminaçăo do lixo urbano, dispóem as leis orgânicas dos Municípios, valendo referir que os detritos perigosos oriundos de fora do território nacional, não podem ingressar no Uruguai, por força de decreto de maio de 1989, firmado na linha do Convênio de Basiléa sobre o controle dos movimentos transfronteiriços de detritos perigosos e sua eliminação. No que pertine à preservação do solo 
nas zonas de exploração agropecuária, a Lei de Impacto Ambiental, exige estudos prévios para projetos como o reflorestamento ou plano de manejo de áreas naturais e as exploraçóes agropecuárias devem aplicar apenas técnicas recomendadas pelo Ministério, tudo como forma de evitar a degradação do solo e a erosão.

Como signatário do Tratado de Tlatalolco (Tratado para proscrição de armas nucleares na América Latina), o Uuguai proibe o uso da energia nuclear com fins bélicose as usinas para produção e transformação de energia nuclear, por expressa disposição da lei de impacto ambiental, somente podem ser autorizadas a funcionar se exibirem relatório favorável. Aliás, dá-se o mesmo em relaçâo às usinas hidrelétricas de mais de 20 megawatts.

Tendo igualmente ratificado (1969) a "Convenção para proteção da Flord, da Fauna e das Belezas Naturais dos países da América", o país disciplina seus parques e reservas nacionais, assim como monumentos naturais e reservas de regióes virgens, através de limitaçóes administrativas

As florestas naturais acham-se protegidas por lei de 1987, que declara de interesse nacional a defesa, melhoramento e a ampliação ou criação dos recursos florestais, havendo igualmente a previsão de uma política florestal nacional.

Por último, de mencionarmos que o parcelamento do solo é objeto de lei específica, que também busca o melhor aproveitamento dos recursos naturais e sua preservação.

Quanto às ações utilizáveis para a defesa do meio ambiente, relevam as disposições do Código Geral de Processo (Lei 15.982), cujo artigo 42 declara legitimados o Ministério Público, qualquer interessado e as Instituições ou Associaçōes de interesse social que garantam uma adequada defesa do interesse comprometido e a Lei 16.112, que autoriza o Ministério de Habitaçāo, ordenamento territorial e Meio Ambiente a promovê-las, tendo efeito "erga omnes" as decisóes delas tiradas. Vale ainda referir que a ação de amparo, prevista pela Lei 16.011 , de 1988, também utilizável contra particulares, pode ser empregada para as açōes de defesa ambiental.

No plano jurídico intemacional, o Uruguai é signatário de diversos tratados, acordos e protocolos, bilaterais ou multilaterais, que envolvem matéria ambiental ou sobre esta dispõem específicamente. Dentre estes, a par daqueles que acima mencionamos a propósito de águas limútrofes (sobre a Bacia da Lagoa Mirime sobre o Rio Uruguay), movimentaçōes transfronteiriças (Convênio de Basiléa) e Parques e Reservas Nacionais (Convenção sobre a proteção da flora, da fauna e das belezas naturais dos países da América), destacam-se:

1. Convênio de Viena para a Proteção da Camada de Ozônio (ratificado em 1988),

2. Tratado Antártico de 1958 (ratificado em 1979),

3. Convenção sobre o comércio internacional de espécies ameaçadas da fauna e da flora silvestre (ratificada pela Lei 14.205)

4. Convenção marco das Naçōes Unidas sobre mudanças climáticas de junho de 1992 (ratificada pela Lei 16.517)

5. Convênio sobte a biodiversidade, de junho de 92 (ratificado pela Lei 16.408)

6. Tratado de proibição de testes nucleares (ratificado pela lei 13.684) 
7 Convenção sobre a conservação de espécies migratórias de animais silvestres, de 1979 (ratificada pela Lei 16.062 ).

De todo este apanhado, deduz-se que a Republica Oriental do Uruguai dispóe hoje de extenso arsenal normativo para empreender a luta por uma efetiva defesa ambiental, com a disponibilidade de instrumentos processuais vigorosos, como o mandado de segurança e a ação civil pública, esta titulada inclusive ao Ministério Público e de efeitos gerais, como acima sublinhamas. Seus compromissos no âmbito internacional a colocam em igualdade de condições com países que se destacam na defesa ambiental, em que pese não seja seu território assolado por problemas tão graves como aqueles noticiados, a exemplo, pelo Paraguai e quiçá pelos enfrentadios pelo Brasil, sobre os quais nos debruçaremos a seguir.

\subsection{A legislação brasileira}

A questão ambiental no Brasil, ao longo das úlumas décadas, vem preocupando diversos segmentos da sociedade e provocando movimentações que se traduzem não só em notícias de jomal, mas também em trabalho profícuo e permanente junto aos Poderes do Estado, notadamente junto ao Poder Legislativo, de que resultou a produção de significativo número de leis, em todas as órbitas, tendentes à proteção do meio ambiente.

Vários Códigos anteriomente à Carta de 1988 já dispunham sobre o tema, comoo Código de Águas (Decreto n²4.643/34), Código Florestal (Lei 4.771/65), Código de Caça ( Lei 5.197/67), Código de Mineração (Dec.-Lei 227/67). Foi, entretanto, na década de 1980, que a preocupação ambiental tornou-se notável no País, com o incremento de grandes esforços e medidas em prol da proteção ambiental. Superava-se, então, o óbice representado pela concepção individualista do direito de propriedade e grandes avanços se fizeram sentir no plano legislativo, com especial destaque à Lei 6.938, de 31.8.1981, que disciplina a Política Nacional do Meio Ambiente, cria o Sistema Nacional do Meio Ambiente, estabelece a responsabilidade objetiva pela indenização ou reparação do dano e legitima o Ministério Público para promoção da responsabilidade civile criminal (art.14, parág. 19) e à Lei 7.347, de 24,7.85, que institui a Ação Civil Pública para a defesa do meio ambiente, consoante anota com propriedade ÉDIS MILARÉ ${ }^{15}$.

Tais instrumentos legais, notadamente pela outorga de competência ao Ministério Público para propôr Ação Civil Pública em matéria ambiental, constituiram notável incentivo a que por tal via se buscasse a proteção jurisdicional ao meio ambiente, fustigado por uma insensata sede de expansão industrial descompromissada com o desenvolvimento sustentável, ou seja, com a compatibilização entre o progresso e a conservação ambiental. Muitas ações começaram então a chegar aos Pretórios, abrindo ao Poder Judiciário a oportunidade de tornar efetivas as regras de proteção, enquanto se municiava a Administração Pública com meios de melhor exercer seu papel de tutor da coisa pública na matéria.

VLADIMIR PASSOS DE FREITAS ${ }^{! 6}$ refere, a propósito da atuação dos Tribunais na defesa do patrimônio público à época, acórdão do Tribunal de Justiça de São Paulo que, por sua ${ }_{15}$ MILARÉ, Édis. Tutela Jurisdicional do Ambiente. In: Revista do Advogado, n. 37, p. 12, 1992. to FREITAS, Vladimir Passos de. A Constituiçäo Federal e a Efetividade das Normas Ambientais. Ed. Revista dos Tribunais, 2000, p. 121-122. 
5⿳â. Câmara Civel, no REO 83.629-1, em 23.3.1987, dispôs sobre indenização por tombamento de prédio histórico na cidade de São Paulo.

Assim, a sociedade já começava a recorrer ao Poder Judiciário através dos insttumentos que a legislação lhe oferecia, para questionar quanto ao meio ambiente. Entretanto, mais rapidamente caminhava o processo de devastação da natureza e se avolumavam as agressões.

Não poderia ser diferente, dado à extensão territorial da País, a diversidade de culturas que abriga e a variedade ambiental, climática, de exploração econômica de riquezas naturais, de produção e de densidade populacional, gerando problemas diversificados nesta área, abrindo um leque considerável de problemas a serem enfrentados.

A consciência de tal realidade e de que é urgente e imprescindível fazer frente ao avanço da atividade industrial, agricola, extrativa, mercantil ou de desenvolvimento urbano que venham em detrimento do ecossistema, gerou na Constituinte de 1987, um especial empenho em colocar ao abrigo do Texto de outubro de 1988 , a proteção ambiental.

Ademais, a questão da integração com outros países da América Latina, ou melhor, a necessidade de conferir-se um caráter náo apenas metcadológico a essa aliança, que vinha sendo de há muito desejada, levou o Constituinte a lançar na novel Carta, as diretrizes básicas para o processo de integração, por via de dispositivo que, consoante veremos, acabou por ditar um perfil abrangente a tal processo, altamente promissor para que nele se envolvesse a questão ambiental.

Assim, no Parágrafo Único do Artigo 4o do Texto, estabeleceu-se:

"A República Federativa do Brasil rege-se nas suas relaçōes internacionais, pelos seguintes princípios:

... (omissis)

Parágrafo Único - A República Federativa do Brasil buscará a integração econômica, política, sociale cultural dos povos da América Latina, visando à formação de uma comunidade latino-americana de nações."

Ainda, no Título VIII da Carta, sobre a Ordem Social, abriu-se um capítulo especial, o de $n^{\circ}$ VI, intitulado "Do Meio Ambiente", composto pelo artigo 225 , incisos e seis parágrafos, in verbis:

"Artigo 225 - Todos tem direito ao meio ambiente ecologicamente equilibrado, bem de uso comum do povo e essencial à sadia qualidade de vida, impondo-se ao Poder Público eà coletividade o dever de defendê-lo e preservá-lo para as presentes e futuras geraçōes.

Parág. $1^{\circ}$ - Para assegurar a efetividade desse direito, incumbe ao Poder Público:

I - preservar e restaurar os processos ecológicos essenciais e prover o manejo ecológico das espécies e ecossistemas;

II- preservar a diversidade e a integridade do patrimônio genético do País e fiscalizar as entidades dedicadas à pesquisa e manipulação de material genético.

III - definir, em todas as unidades da Federação, espaços territoriais e seus componentes a serem especialmente protegidos, sendo a alteração e a supressão permitidas somente através de lei, vedada qualquer utilização que comprometa a integtidade dos atributos que justifiquem sua proteçäo; 
IV - exigir, na forma da leí, para a instalaçăo de obra ou atividade potencialmente causadora de significativa degradação do meio ambiente, estudo prévio de impacto ambiental, a que se dará publicidade;

$\mathrm{V}$ - controlar a produção, a comercialização e o emprego de técnicas, métodos e substâncias que comportem risco para a vida, a qualidade de vida e o meio ambiente;

VI - promover a educação ambiental em todos os níveis de ensino e a conscientização pública para a preservação do meio ambiente;

VII - proteger a fauna e a flora, vedadas, na forma da lei, as práticas que coloquem em risco sua função ecológica, provoquem a extinção de espécies ou submetam os animais a crueldade.

Parág. $2^{\circ}$ - Aquele que explorar recursos minerais fica obtigado a recuperar o meio ambiente degradado, de acordo com solução técnica exigida pelo órgão público competente, na forma da lei.

Parág. 3ำ - As condutas e atividades consideradas lesivas ao meio ambiente sujeitarão os infratores, pessoas físicas ou jurídicas, a sançōes penais e administrativas, independentemente da obrigação de reparar os danos causados.

Patág. 4⿻ - A Floresta Amazônica brasileira, a Mata Atlântica, a Serra do Mar, o Pantanal Mato-Grossense e a Zona Costeira são matrimônio nacional, e sua utilização far-se-á, na forma da lei, dentro de condições que assegurem a preservação do meio ambiente, inclusive quanto ao uso dos recursos naturais.

Parág. 5- São indisponíveis as terras devolutas ou arrecadadas pelos Estados, por açôes discriminatórias, necessárias à proteçāo dos ecossistemas naturais.

Parág. $6^{0}$. As usinas que operem com reator nuclear deverão ter sua localização definida em lei federal, sem o que năo poderão ser instaladas."

Vê-se, pois, que a Constituição Federal de 1988 estabeleceu feição ampla à aliança que a Nação deveria intentar com outros países da América do Sul, de maneira a integrar-se com estes nos planos econômico, político, social e cultural, formando uma comunidade. Ao fazê-lo, pois, deixou claro que a integração há de ser abrangente, envolvendo aspectos variados $\mathrm{e}$, portanto, também aqueles que dizem com o bem-estar dos povos, e, portanto, com um meio ambiente sadio que o propicie.

Ainda, na linha das mass atualizadas doutrinas ambientalistas, a Carta prevê a observância do princípio da precaução, do desenvolvimento sustentado, impóe o estudo do impacto ambiental para projetos que impliquem em potencial ou efetivo dano, consagra o princípio do poluidor-pagador, institui a responsabilidade administrativa e penal pelas atividades lesivas tanto das pessoas físicas como das jurídicas declara patrimônio nacional diversas ecossistemas e, sobretudo, impõe uma série de condutas ao Administrador, para dar efetividade à proteção ambiental.

Merece especial destaque a definição do meio ambiente sadio como patrimônio de todos e consequente direito geral de todos, com correspondente obrigatoriedade generalizada de guarda e preservação (partilha de responsabilidade, como fundamento constitucional para a legitimidade ativa em matéria de um direito que é eminentemente difuso, como o ambiental). 
Também em dispositivos esparsos, dispõe o Texto sobre matéria ambiental:

a) legitimando qualquer um a propor ação popular em defesa, entre outros bens, do meio ambiente (Art. 5, Inciso LXXIII);

b) estabelecendo o princípio da não tipicidade dos direitos fundamentais e garantindo, neste terreno, a observância dos tratados intemacionais ratificados (Art,5ㅇ, LXXII, parág, $2^{\circ}$ );

c) declarando bem da União as terras devolutas indispensáveis à preservação ambiental (Art.20,II);

d) instituindo sistema nacional de gerenciamento de recursos hídricos (art.21,XIX);

e) instituindo a competência comum (competência material) das Pessoas Políticas para a proteção dos documentos, obras e outros bens de valor histórico, artístico e cultural, os monumentos, as paisagens naturais notáveis e os sítios arqueológicos, bem como do meio ambiente e das florestas, fauna e flora e saneamento básico (Art. 23,III, VI, VII e IX);

f) estabelecendo a competência concorrente (competência legislativa) da Uniăo, dos Estados e do Distrito Federal para legislar sobre 1) florestas, caça, pesca, fauna, conservação da natureza, defesa do solo e dos recursos naturais, proteção do meio ambiente c controle da poluição, 2) proteção ao patrimônio histórico, cultural, artístico, turístico e paisağístico, 3) responsabilidade por dano ao meio ambiente, ao consumidor, a bens e direitos de valor artístico, estético, histórico, turístico e paisagístico (Art.24, VI, VII, VIII). Vale registrar que aos Municípios está reservada competência legislativa suplementar e em matéria de interesse local (Art.30,le II);

g) estabelecendo como função institucional do Ministério Público promover o inquérito civil e a ação civil pública para a proteção do patrimônio público e social, do meio ambiente e de outros interesses difusos e coletivos (Art.129,III);

h) permitindo ao Poder Público o tombamento, desapropriação e acautelamento e proteção de bens do patrimônio cultural (art.216, parág. 19);

i) atribuindo à lei federal o poder de garantir os meios legais de defesa contra a propaganda de produtos, práticas e serviços que possam ser nocivos à saúde e ao meio ambiente (Art.220,parág. ${ }^{2}, \mathrm{II}$ ).

Con tal abrangência, pode-se afirmar que a Constituição Federal do Brasil é um dos Textos mais avançados do mundo, em matéria ambiental, proporcionando meios eficientes de defesa no plano administrativo, penal e civil.

Sobre tal lastro, desenvolveu-se ampla normatividade, tanto na órbita federal como na órbita estadual e municipal, dada a competência concorrente que já vimos existir entre a União, os Estados , Distrito Federal e Municípios.

Na órbita federal, destacamos:

1. A Lei 6.938, de 31.8.81, que dispóe sobre a Política Nacional do Meio Ambiente;

2. A Lei 6.171, de 4.12.1988, alterada pela Lei 8.421 , de 23.11.93, que regulamenta o uso e a preservaçăo do solo agrícola;

3. A Lei 8.078, de 11.9.90, que institui o Código de Defesa do Consumidor ealtera dispositivos da Lei $7347 / 85$ (Lei da Ação Civil Pública), estendendo à defesa dos direitos e 
interesses difusos, coletivos e individuais, no que for cabivel, os dispositivos de seu Título III ( (Da Defesa do Consumidor em Juízo), com previsão de concessão de medida liminar;

4. A Lei 8.974, de 05.01.1995 (Lei da Biossegurança), que regulamenta os incisos II e V do parágrafo $1^{\circ}$ do art.225/CF, nomatiza o uso das técnicas de engenharia genética e liberaçăo no meio ambiente de organismos genéticamente modificados, autoriza o Poder Executivo a criar a Comissão Técnica de Biossegurança (CTNbio) e dá outras providências;

5. A Lei 9.433 , de 08 de janeiro de 1997, que institui a Política Nacional de Recursos Hídricos;

6. A Lei 9.605 , de 12.2.1998, que define ilícitos e crimes ambientais, dispõe sobre as sançóes administrativas, civís e penais respectivas, estabelece a responsabilidade inclusive penal das pessoas jurídicas e adota a doutrina da desconsideração da pessoa jurídica quando necessária ao ressarcimento dos prejuízos por esta causados.

Merece destaque, no texto, o capítulo referente à cooperaçăo internacional para a preservação do meio ambiente, com os artigos $77 \mathrm{e} 78$, dispondo que o Governo brasileiro, em tema de meio ambiente, prestará a necessária cooperação a outro país, sem qualquer ônus, quando solicitado para a produção de prova, exame de objetos e lugares, informaçóes sobre pessoas e coisas, etc. e que para a reciprocidade da cooperação internacional, deve ser mantido sistema de comunicações apto a facilitar o intercâmbio rápido e seguro de informações com órgãos de outros países.

7. O Decreto 2.519, de 16.3.1998, que promulga a Convençăo sobre diversidade Biológica, assinada no Rio de Janeiro, em 05.06.1992;

8. A Lei 9795, de 27.4.1999, que dispõe sobre a educação ambiental;

9. A Lei 9.984, de 17.7.2000, que dispõe sobre a criação da Agência Nacional de Águas - ANA, como entidade federal de implementação da Política Nacional de Recursos Hídricos e de coordenação do sistema Nacional de Gerenciamento de Recursos Hídricos;

10. A Lei 9985 , de 18.7 .2000 , que regulamenta o art. 225 , parág. $1^{\circ}$, incisos I,II,II e VII da Constituição Federal e institui o Sistema Nacional de Unidades de Conservação da Natureza.

Os tipos de ações que podem ser empregadas para postular a proteção jurisdicional na matéria são vários: ação ordinátia, ação cautelar, ação civil pública, ação popular, mandado de segurança coletivo.

Trata-se, pois, de um conjunto normativo bastante satisfatório, que disponibiliza às autoridades públicas, ao Ministétio Público, às ONGs e ao particular, um excelente arsenal para enfrentar as açōes lesivas, consoante bem anota SILVIA CAPPELLI ${ }^{17}$, considerando o arcabouço legislativo ambiental brasileiro como um dos mais modernos da atualidade.

Entretanto, é notória a falta de meios efetivos para uma satisfatória ação fiscalizadora do Estado, que, ao adotar um modelo econômico de enxugamento da máquina administrativa e desmobilização dos servidores, nesta década de 90 , acabou por criar ainda maiores dificuldades ao controle estatal sobre as atividades de particulares que ofendam à natureza e desobedeçan ${ }_{17}$ CAPPELLI, Silvia. Responsabilidade penal da pessoa juridica em matéria ambiental: uma necessária refiexão sobre o disposto no art. 225, pard́g. $3^{\circ}$, da Constituiçăo Federal. In: Revista Estudos Jurídicos. Săo Leopoldo: Universidade do Vale do Rio dos Sinos, v. 28, n. 72, Jan./abr., 1994. 
à lei. O território é vastíssimo, o material humano e os meios de atuação são escassos, de maneira que o sucesso da defesa ambiental depende, em muito, da colaboração de toda a sociedade que, "ultima ratio", é a titular do patrimônio (natural, cultural artificial ou do trabalho) a ser protegido. Para tanto, é necessário um intenso trabalho de divulgação de conhecimentos e de educação ambiental e de incentivo à participação popular, campo no qual ainda muito há que fazer-se.

No campo intemacional, de registrar-se que o Brasil é signatário de inúmeros Tratados, Acordos, Convenções e Protocolos que envolvem proteção ambiental ou dela tratam específicamente. Merecem destaque;

1. Convenção para Proteção da Flora e da Fauna e das Belezas Cênicas Naturais dos Países da América, Washington, em vigor no país desde 26.11.65;

2. Convenção Internacional para a Regulamentação da Pesca da Baleia, Washington, em vigor desde 18.8.50;

3. Tratado da Antártida, Washington, com adesão brasileira em 16.5.75;

4. Convenção relativa à proteção do Patrimônio Mundial, Cultural e Natural, Paris, em vigor no país em 2.12.1977;

5. Convenção sobre Comércio Internacional das Espécies da Florae da Fauna Selvagens em perigo de Extinção, Washington, em vigor no Brasil desde 12.11.1987;

6. Tratado de Cooperação Amazônica, Brasilia, ratificado pelo Brasil em 10.12.1978;

7. Convenção sobre o Direito do Mar, Montego Bay, em vigor em 16..11.1994;

8. Convenção de Viená para a proteção da Camada de Ozônio, Viena, ratificado em 12.2.1990;

9. Protocolo de Montreal sobre Substâncias que Destroem a Camada de Ozônio, Montreal, ratificado em 19.3.1990;

10. Convenção de Basiléa sobre o Controle de Movimentos Transfronteiriços de Resíduos Perigosos e seu Depósito, Basiléia, adesão brasileira em 15.10.1992;

11. Convenção sobre a Mudança de Clima, Rio de Janeiro, ratificado em 28.2.1994;

12. Convenção sobre Diversidade Biológica, Rio de Janeiro, ratificado em 28.2.1994.

No plano institucional, já com a criação do Sistema Nacional do Meio Ambiente SISNAMA, através da supramencionada Lei 6.938/81, vários orgãos foram estruturados para compô-lo, como o CONAMA (órgão consultivo e deliberativo), o Ministério do Meio Ambiente, (órgão central) e IBAMA (órgão executor), além de órgãos setoriais, seccionais e locais, com competências específicas.

Necessário novamente sublinhar que toda a estrutura montada é ainda insuficiente para fazer frente às dimensóes do problema ambiental no Brasil e a curto prazo não se vislumbram sinais de fortalecimento da máquina administrativa, o que significa que as dificuldades nessa área continuarão a se verificar nos próximos anos.

Aliás, neste ponto vale mencionar a sagaz observaçāo que faz ANTÕNIO HERMAN V. BEN]AMIN'18:

18 ANTÕNIO HERMAN V. BENJAMIN. Introduçäo ao Direito Ambiental Brasileiro. In: Revista de Direito Ambiental, n. 14, p. 49-82, abr.jun. 1999. 
"O Brasil, afirma-se, tem hoje um dos mais avançados sistemas de proteção jurídica do meio ambiente. Prioritário para o futuro (e para o presente) já não é, no essencial, legislar. Jáo fizemos. O que se espera agora dos órgãos ambientais e dos cidadãos, organizados ou não, é o cumprimento das exigências legais, que, com frequência, nada mais são do que letra morta.'

\section{CAMINHOS QUE SE ABREM À DEFESA AMBIENTALNOMERCOSUL}

De tudo o que até aqui vimos, extrai-se que um grande trabalho já foi realizado no âmbito do Mercosul e da legislaçāo interna de cada Estado-Membro no sentido de aprimorar a defesa ambiental e se propiciar o desenvolvimento sustentável na região. Há um empenho constante dos juristas e doutrinadores em dotar a aliança es países que a integram de excelentes instrumentos para a implementação de uma política ambiental intema e comunitária que assegure o melhor nivel de proteção possível nos dias de hoje. O esforço é constante e se traduz não só na produção multiplicada de diplomas das mais diversas hierarquias tratando sobre a questáo ambiental, como na produção de doutrina especializada sólida e abundante, atividades em que vem pontificando o Brasil.

$\mathrm{Na}$ base de todo esse esforço, como sinalizador dos caminhos a seguir e a evitar, está, naturalmente, a experiência européia. Seu significado é imenso, quer em face do alcance territorial resultante da adesão em massa no continente, quer pelo sucesso de que se reveste no campo econômico.

Assim, respeitadas as peculiaridades próprias do processo integracionista europeu que, diferentemente do que se verifica no Mercosul, constituiu verdadeiro Mercado Comum, tendo ultrapassado a etapa de Zona de Mercado Comum (livre comércio, uniáo aduaneira e livre circulaçăo de pessoas, serviços, bens, mercadorias e capitais) e ingressado à etapa de Zona de União Política e Econômica, com a ratificação do Tratado de Maastricht (metcado comum, sistema monetário comum, política externa e de defesa comuns), a experiência de integração européia constitui referencial indeclinável para a Anérica do Sul, seja no encaminhamento das questóes econônicas, seja no encaminhamento das várias políticas coligadas, em especial a do meio ambiente, do qual ora se trata.

Todavia, é também preciso de que assinale não ser possível a pura e simples importação das soluçôes adotadas no âmbito da União Européia, não só pelas peculiaridades do processo integrativo lá verificado, mas também em face da diversidade das questóes ambientais enfrentadas pela América Latina. Aqui há escasso desenvolvimento industrial e muita atividade exploratória, dificuldade de recursos financeiros, empobrecimento generalizado, escassez de elemento humano especializado e até uma cultura de exploração desarrazoada dos recursos naturais, tidos, até algumas décadas atrás, como oriundos de um manancial inesgotável que transformou o continente em fornecedor de matéria-prima para as grandes empresas multinacionais dos quais é essencialmente importador.

O Mercosul não é nem pode ser uma cópia da Uniăo Européia, florescendo ambos os processos integracionistas em contextos totalmente distintos. Entretanto, deve aproveitar - e já o faz, sem dúvida - a experiência européia no encaminhamento dos mais diversos aspectos de sua aliança e, dentre eles, o ambiental, onde a tradição da Comunidade produziu escólio muito 
proveitoso, como o instrumento do Estudo de Impacto Ambiental (EIA), a que já nos referimos, e que hoje integra a legislação de grande número dos países.

É imperioso salientar que o sucesso até hoje alcançado no seio da Uniâo Européia está alicerçado na ampla participaçăo populare no convencimento dos setores produtivos de que é mais lucrativo produzir respeitando a Natureza, sabendo utilizar os recursos naturais, evitando toda e qualquer forma de poluição, degradação ou perigo. Trata-se, pois, de dois pilares de sustentação cuja estruturação implicaram na adoção de diversas medidas e procedimentos.

Quanto ao apoio popular, é preciso que se diga, não pode existir sem a divulgação das informações adequadas, seja a nível de formação educacional, seja a nível de conhecimento sobre os fatos em andamento. É indispensável que a educação ambiental seja firme e efetiva, propiciando os meios para o reconhecimento de práticas deletéreas, orientando a conduta protetiva e a higiene urbana desde a mais tenra idade até o nível superior, passando pelo aprimoramento técnico especializado daqueles que querem se profissionalizar na área. Étambém necessário que a população conheça os projetos produtivos já quando ainda em planta e todas as suas implicações, bem como as ações governamentais desenvolvidas para assegurar a preservação ambiental. Indispensável também é que se mobilizem as forças populares no sentido da fiscalização das atividades privadas e públicas.

Para tanto, é de especial importância a atuação do Poder Público, implementando as políticas educacionais adequadas, promovendo a divulgação do trabalho estatal e dos projetos em andamento e incentivando o apoio e fiscalização popular. É também indispensável que se conte com o concurso da mídia na consecução dessa tarefa, que não é pequena e também requer aporte financeiro, quase sempre pouco disponível.

Os subsídios que nos confere a experiência européia apontam também para o papel relevantíssimo que nela exerceram e exercem as $O N G$ 's ambientalistas, instituições que devem merecer o melhor prestigiamento pelo esforço que empreendem nesse campo da conscientização popular e da ação efetiva junto à fonte de destruição/perigo. Seu fortalecimento no âmbito da América Latina, através da divulgação do importante trabalho que desenvolvem, do auxilio à sua estruturação e especialização seriam medidas aconselháveis, sem dúvida .

Quanto à conscientização dos segmentos envolvidos no processo produtivo, é questão bem mais complexa, pois, como têm em vista, precipuamente, o alcance de lucros, tais setores não se acham seduzidos por medidas que encareçam os produtos ou criem embaraços à sua comercialização, demandando tecnologias modemas e dispendiosas de fabricação ou cultivo . Controlando os meios de produção, tendem a ver tais medidas como um verdadeiro empeço ao seu progresso individual, obstáculo odioso ao seu sucesso empresarial e que urge afastar ou contonat.

Assim, a pura e simples oneração do processo produtivo pela adoção de medidas de proteção ambiental encontra grande resistência em tais segmentos. É necessário que se tomem convictos de que a adoção de tais medidas virá também em seu proveito financeiro, através de uma melhor colocação do produto no mercado, da possibilidade de reaproveitamento de tecursos, de melhor enfrentamento da concorrência, da preservação dos meios produtivos. 
Quanto a tal aspecto, a experiência européia nos mostrou o sucesso que foi a adoção do sistema do "selo verde", o reconhecimento do produto fabricado corretamente do ponto de vista ecológico, e de correta utilização frente ao meio ambiente. Difundida a idéia de que tais produtos são melhores para a saúde humana e para o equilibrio ambiental, as populações passaram a consumí-los ou utilizá-los preferencialmente, o que os tomou especialmente atrativos para os segmentos da produção agropecuária e industrial.

A harmonização/unificação das legislações ambientais é outro exemplo europeu a ser seguido, com atenção especial à questão hoje vivida no seio da Comunidade, quando à internação das diretivas comunitárias e o grau de efetividade das medidas a nível interno. Alguns doutrinadores, como MARISTELA BASSO ${ }^{\circ}$, apontam tal harmonização como medida indispensável ao esforço que se desenvolve no seio do Mercosul em prol do meio ambiente. Da mesma forma, OSVALDO MANTERO DE SAN VICENTE20, enfatiza a necessidade de criação de normas supranacionais para evitar a possibilidade de um "dumping" originado na falta de proteção ambiental em um dos países. É efetivamente, medida que se impóe, pata permitir o avanço conjunto e o trato unificado das questớes comuns, sem afetar a livre concorrência no mercado que se pretende unificar.

Mas já muitos passos foram dados em tal sentido, e alguns deles acham-se especificamente mencionados neste trabalho. A consecução de tal objetivo forçosamente há de passar por diversas etapas, respeitadas as exigências e as condiçōes econômico-financeiras de cada EstadoParte e dos segmentos de sua economia, mas, como frisamos, o esforço continua, já tendo produzido, inclusive, um projeto de Protocolo Adicional ao Tratado de Assunção em Matéria de Meio Ambiente. Todavia, embora necessária e até indispensável, a hamonização legislativa não é medida que, isoladamente, assegure a efetividade da proteção ambiental no âmbito comunitário.

Portanto, tudo está a indicar que as maiores dificuldades neste terreno não se encontram na deficiência do suporte jurídico, antes radicam na extrema dificuldade de implementação das normas protetivas, dos projetos de desenvolvimento sustentado, enfim, de uma avançada política ambiental.

Sem dúvida, o Mercosul, a par da utilização da expetiência européia, terá que fornular suas próprias soluçóes, quer para o fortalecimento da aliança intentada, quer para a condução das diversas políticas embricadas nesse processo de integração, inclusive a ambiental.

Para tanto, tem-se que deverá trabalhat políticamente na busca de suporte internacional às ações e medidas necessárias à implementação de seus programas e normas e na mudança de paradigma comportamental até hoje adotado no concerto das Naçôes. Em outras palavras, considerando que o direito ambiental é hoje tido como extensão dos direitos fundamentais do Homem, de dimensão universal, ao atuar na proteção do patrimônio da Humanidade que é o meio ambiente saudável, o Mercosul, como pessoa de direito internacional deve reivindicar o apoio de todas as Naçóes desenvolvidas e que se encontram em condiçóes de colaborar; traduzido em financiamento sem retorno para a cobertura de todas as ações ambientais a

19 Basso, op.cit., p. 401-404.

20 SAN VICENTE, op. cit., p. 23-24. 
serem desenvolvidas, apoio técnológico e suporte na preparação dos recursos humanos indispensáveis.

Afinal, se a formação do Mercado Comum do Sul teve por objetivo fazer frente aos grandes blocos econômicos e alavancar o progresso das Nações nele integradas, com o incentivo da própria ONU, nada mais natural que o fortalecimento decorrente dessa integração seja usado no plano político em prol da superação dos obstáculos financeiros que se erguem à implementação de uma política ambiental que assegure a efetividade da preservação e do desenvolvimento sustentável no âmbito do Mercosul.

Certo que não é tarefa fácil, mas urge empreendê-la, para viabilizar o processo de inserção dos Estados-Membros no mundo das nações desenvolvidas, pela via já consagrada do desenvolvimento sustentável, ou seja, da conciliação do incremento das atividades produtivas com a preservação do meio ambiente, ou, na feliz definição adotada pela Comissão Mundial sobre Meio Ambiente e Desenvolvimento, "aquele que atende às necessidades do presente, sem comprometer a capacidade das futuras geraçôes atenderem às suas próprias necessidades", consoante ensina ÉDDS MILARÉ21.

Vale lembrar, neste campo financeiro, a proposta feita em nome dos Estados Unidos da América, por seu então Presidente, GEORGE BUSCH, em discurso feito em Washington, em 27.6.1990, integrante da chamada "Iniciativa das Américas", no sentido de que se vendesse parte dos créditos americanos pendentes a fim de facilitar a troca da dívida por inversões de capital e a sua troca por medidas sobre o meio ambiente, assim como a criação de fundos ambientais, compostos pelos pagamentos em moedas locais e destinados ao financiamento de projetos ambientais nos países devedores. A proposta, consoante assinala EDUARDO A. PIGRETTI ${ }^{22}$, mereceu críticas por parte dos países da América Latina, por constituir medida tímida, face à manutenção da obrigatoriedade de pagamento de milhóes de dólares aos Estados Unidos, ou implicar indevida ingerência em assuntos de soberania desses países.

\section{CONCLUSÃO}

Já vimos que, se, por um lado, temos ainda considerável desnível teórico (legisłativo) e prático (implementação) no trato daquestão ambiental nos paísesque compöemo Mercosul, estamos trabalhando árduamente na busca da necessária harmonização.

Arica expetiência européta tem, nesse processo, conslituido fonte de inspiraçãoe de orientação, aser adotada com os cuidados que se impöem para evitar a pura e simples transposição, o mais das vezes atéinviável do ponto de vista técnico-juñ́dico, haja vistao caráter supranacional da estrutura comunitária, ausenteno Mercosul.

Os Tratados envolvendo ecossistemas comuns ou regiōes alvo de empreendimentos comuns estão emplenoestudoc regulamentação.

Tudo caminha, pois, para o aptimoramento do direito material ambiental e do instrumental jurídico necessário à sua realização.

\footnotetext{
2: MILARÉ, Ėdis. Tutela Jurisdicional do Ambiente. In: Revista do Advogado. São Paulo: Ed. Associação dos Advogados de São Paulo AASP, n. 73, p. 7-8, set. 1992.

${ }^{22}$ PIGRETTl, Eduardo A.. Derecho Ambienial. Buenos Aires: Ediciones Depalma, 1993, p. 189-193.
} 
Neste contexto, é de enfátizau-sea idéia, jáacalantadapor vários internacionalistas ambien talistas, qual seja a de criação de una Corte Ambientalista do Mercosul.

Sim. Se a aliança caminha para a harmonizaçăo de sua política em tema de meio ambientee do próprio direito ambiental material e instrumental, o próximo passo para oaperfeiçoamento do sistena há que ser a instituição de um Tribunal especializado que passa aplicaro direito e sancionar as condutas que the sejam contrárias. Só assim se formará jurisprudência firme sobre a interpretação das normas mais complexase se daráa a indispensável coesão e respeitabilidade ao sistema, efeitos que não se logra alcançar quando a jurisdição é exercida em cada Estado-Membro, pulverizada num sem número de juízos e julgadores, a maionia sem a desejável especialização.

Discorrendo sobre a idéia de criação de uma corte intemacional, VLADMMRPASSOSDE FREITAS ${ }^{23}$ refere que a mesma teve origemem Roma, em 1988 quando se criou um comitê para o trato do assunto, mais tarde transformado na ONG "International Court of th Environmnt Foundarion" (ICEF). Inicialmente, o objetivo era a imposição de sanções morais aos concaminadores, mas hoje jáse pensa em Corte compoder de impor sançōese, na VIIConferência Internacional ICEF, realizadana Itália, em 1997, jáse acertou que a organizaçăo promoverá a instituição de "cortes regionais ambientais" para julgamentos moraisem todos os continentes.

Aliás, o mesmo Autor lembra a experiência pioneira dacriação do Tribunal de Terras e Meio Ambiente, no Estado de New South Wales, Austrália (op.cit,pag.50), Corte que se acha em pleno funcionamento desde 1980 , comstatus de tribunal superior estadual, demonstrando que a especialização no tenna ambiental propicia decisões muito mais apropriadas e ajustadas à evoluçăo conscante e acelerada do Direito Ambiental. Discorrendo sobre ela, ] ustice PAULSTEIN ${ }^{24}$ atribui parte do sucesso daquela experiência pioneira ao fato de que os julgamentos são feitos com participação de assessotes leigos, ou seja, técnicos em várias áreas, que participam do processo de tomada de decisões.

Assim, se na doutrina ambiental intemacional se sustenta a conveniênciae aténecessidade da criação de uma Corte Intemacion al do Meio Ambiente, juntoà ONU, como aponta TOSHIOMUKA25, referindo inclusiveà Recomendaçãon ${ }^{0} 11$, da Reunião de Limoges, de 1990 , reunindo juristas ambientais de todbo mundo, com mais razão se pode pretendera instalação de una Conte Internacional Ambiental do Mercosul, com jurisdição sobre o território do bloco e melhor preparo na legislação comunitária específica.

Misteré que preparemoso temeno para este Tribunal especializado, que há de vir para auxiliarà consolidação do Mercosul como processo de integração qque a Nação, por sua Carța, já manifestou pretender tenha também uma dimensão política, cultural e social, além da econômica, fortalecendo uma verdadeira comunidade, voltada ao desenvolvimento dos povos da América Latina.

Para tanto, no âmbitoputramente acadêmico, énecessário que se trabalhe na especialização dos operadores do Direito, em especial daqueles que se voltam aoestudo do moderno direito intemacional e, portanto, tambén do direito comunitátio, familarizando-os como trato do Direito Ambiental nesta florescente comunidade intemacional queéo Mercosul.

${ }^{23}$ FREITAS, op. cit., p. $5 \uparrow-52$.

${ }^{24}$ STEIN, Paulo. Direito Ambiental, mito ou realidade? Um tribunal especializado em Meio-Ambiente: uma experiência australiana. In: FREITAS, Vladimir Passos de (Org.). Direito Ambiental em Evolução. Curitiba: Ed. Juruá, 1998, p. 219-240.

25 MUKAl, Toshio. Direito Ambiental Sistematizado. 2.ed. Rio de Janeiro: Ed. Forense Universitária, ^994, p. 163 et seq. 